\section{African Meteorological Workers}

Training of Africans in the Meteorological Department in Kenya was started some years ago and increasing numbers are now joining the Service. Most of the workers have been educated at African schools and have passed the Junior Secondary School Examination. An entrance examination to the Department ensures that the candidates have a reasonably sound knowledge of arithmetic, English, physics and geography. Sections of the Service include observing, clerical climatological work and printing. Africans trained for the Observing Section are liable to be sent anywhere in Kenya and a few have gone as far as Uganda and Tanganyika Territory. A course beforehand of a few months duration enables these men to read instruments such as thermometers and barometers. They learn to distinguish between the different types of clouds and to report weather visibility and wind force and direction. Training is also given in pilot balloon observations, and Africans have shown remarkable adaptability in this difficult task. The Climatological Section covers a wide field and here also Africans are not lacking in ability. Printing is a task to which the African takes readily, and all reports, summaries and rainfall bulletins are printed on the premises, as well as all the necessary forms for the Department. Rates of pay and facilities for leave are the same as for other Government Departments. Hours are also similar, except for the observers, whose duties must necessarily be irregular.

\section{Integration of Research in the United States}

Dr. R. H. Heindel, director of the American Library of the Office of War Information, has contributed to the May issue of Agenda an article "The War and Post-War Integration of Research Activities in the United States", which is of considerable general interest to scientific workers. The article gives a comprehensive picture of the extensive development of decentralized research in the United States, especially in science, to implement the war research programme, and should be read in conjunction with Dr. Karl T. Compton's Pilgrim Trust Lecture (NATURE, May 29, p. 601). The integration of Federal and non-Federal research facilities is a war problem of the highest importance in view of the limited number of specialists and the need for protecting the nation's research structure, now and in post-war reconstruction. The Federal Government has for many years been developing, with all kinds of re. sponsible research agencies, patterns of procedure and co-operation which have proved useful during the War and should not be without value in considering the organization of research in Great Britain and in the British Commonwealth, and particularly the relations between Government researchinstitutions and the universities. The types of investigation suitable for 'farming out' or contracting are almost unlimited. Contracting for research and co-operative programmes depend on the existing personnel, the fields of study, the nature of the problems, the structure of the official and private agencies and the community of agencies willing to serve the nation as a whole, and success here requires more coherence and direction in the formulated needs of the Government. Government demands for certain types of research may encourage within the universities and elsewhere a greater use of inter-departmental and inter-disciplinary approaches to research projects.
In regard to detail, Dr. Heindel refers to an impressive programme of research development and the most extensive use of contracting with substantial funds, centring about the Office of Scientific Research and Development, within the Office for Emergency Management, to which are attached an Advisory Council, the National Defence Research Committee and the Committee on Medical Research. One of the most successful contracts exists between the Public Roads Administration and the National Resiarch Council for the Highway Research Board, while the U.S. Office of Education has also stimulated and participated in numerous co-operative research projects with State and private agencies. The Bureau of Foreign and Domestic Commerce has been extending its co-operation with university schools of business and departments of economics, and acts as a clearing house for business and economic research. Moreover, in the use it makes of the results of scientific study in its legislative duties and in its responsibility as the appropriating authority for the Federal research programme, Congress occupies an important place in the research structure of the nation. In this article, Dr. Heindel's map of research in the United States is not always as clear as it might be, but he indicates the right questions to which answers must be forthcoming if the machinery for co-ordination, for co-operation and contracting is to be used with success and the results of research conveyed to the proper people.

\section{"Abstracts from Cancer Research"}

THE problems of the nature and possible treatment of malignant disease are studied in many laboratories and results are published in different journals. It is difficult for any worker to keep in touch with all the published work. Excellent summaries of papers were published for many years in the Cancer Review, the publication of which was unfortunately suspended about ten years ago. Since then abstracts have been available in the American Journal of Cancer, which has now been replaced by Cancer Research. The "Abstracts from Cancer Research" are published separately and the first volume covers the year 1941. The summaries are grouped under the main headings of experimental research (including carcinogenic compounds, hormones, viruses, genetics, physical factors, radiation, chemosurgery, biochemistry and nutrition-chemotherapy, immunology, leukæmia, transplantation and tissue culture), comparative oncology, clinical and pathological reports, statistics and cancer control and public health. The production seems admirable and should be of great value to cancer research workers. This new journal is published in America by the International Cancer Research Foundation, but Prof. E. L. Kennaway and Dr. W. E. Gye arrange for the abstracting of articles appearing in publications in the British Commonwealth.

\section{Laryngology and Folk-lore}

IN a recent paper ( $J$. Laryng. and Otol., 57, 527 ; 1942 ) on this subject, Dr. J. D. Rolleston states that up to the time of Morgagni (1682-1771), who described several cases in which it was diseased, the larynx occupied a very subordinate place in pathology, its existence being almost ignored by ordinary students of medicine. On the other hand, there are several references in classical antiquity to popular miethods of dealing with diseases of the throat, as 